UDK 577.1 : 61

ISSN 1452-8258

J Med Biochem 39: 422-427, 2020

\title{
PLATELET LUMIAGGREGATION TESTING: REFERENCE INTERVALS AND THE EFFECT OF ACETYLSALICYLIC ACID IN HEALTHY ADULTS
}

\section{ISPITIVANJE LUMIAGREGACIJE TROMBOCITA: REFERENTNI INTERVALI I EFEKAT ACETILSALICILNE KISELINE KOD ZDRAVIH ODRASLIH OSOBA}

\author{
Alenka Trampuš Bakija1 , Janez Jazbec ${ }^{2}$, Barbara Faganel Kotnik² \\ ${ }^{1}$ Institute of Special Laboratory Diagnostic, University Children's Hospital, \\ University Medical Centre Ljubljana, Ljubljana, Slovenia \\ ${ }^{2}$ Department of Haematology and Oncology, University Children's Hospital, \\ University Medical Centre Ljubljana, Ljubljana, Slovenia
}

\begin{abstract}
Summary
Background: Light transmission aggregometry with lumiaggregometry are methods commonly recommended as a first-line test in platelet dysfunction diagnostic work-up. They are poorly standardized and usually performed in specialized laboratories. For proper interpretation, each laboratory should establish its own diagnostic approach in order to recognize abnormal aggregation patterns. The aim of this study was to measure plasma lumiaggregometry with basic agonists to establish the analyzer-reagent reference intervals (RI) for adults and to test the method response to aspirin.

Methods: The Chrono-Log Model 700 lumiaggregometer using Chrono-Par and Chrono-lume reagents (Chrono-Log Corp., Havertown, PA, USA) was used to measure the maximal aggregation and adenosine triphosphate release using adenosine diphosphate $(2 \mu \mathrm{mol} / \mathrm{L})$, collagen $(2 \mu \mathrm{g} / \mathrm{mL})$, arachidonic acid $(1 \mu \mathrm{mol} / \mathrm{L})$, epinephrine $(5.5 \mu \mathrm{mol} / \mathrm{L})$ and ristocetin $(1.25 \mathrm{mg} / \mathrm{mL})$, and thrombin $(1 \mathrm{U} / \mathrm{mL})$. The effect of aspirin on platelet aggregation and granule release was inspected.

Results: RIs derived from 40 healthy adults were calculated using the non-parametric approach. Wider intervals and low lower limits were determined for weak agonist as well as absence or impaired aggregation in up to one of 7 healthy controls. The response of platelets to aspirin shows response comparable to previously reported study.
\end{abstract}

\section{Kratak sadržaj}

Uvod: Optička agregometrija i lumiagregometrija su metode koje se obično preporučuju kao test prvog reda u dijagnostičkoj disfunkciji trombocita. Loše su standardizovani i obično se izvode u specijalizovanim laboratorijama. Za pravilno tumačenje, svaka laboratorija treba da uspostavi svoj dijagnostički pristup kako bi prepoznala abnormalni obrazac agregacije. Cilj ove studije je bio da se izmeri lumiagregometrija u plazmi sa osnovnim agonistima kako bi se utvrdio referentni interval reagensa i analizatora (RI) kod odraslih osoba i testirala reakcija metode na aspirin. Metode: Korišćen je lumiagregometar Chrono-Log Model 700 koji koristi Chrono-Par i Chrono-lume reagense (Chrono-Log Corp., Havertown, Pensilvanija, SAD) za merenje maksimalne agregacije i oslobađanja adenozin-trifosfata korišćenjem adenozin-difosfata ( $2 \mu \mathrm{mol} / \mathrm{L})$, kolagena (2 $\mu \mathrm{g} / \mathrm{mL})$, arahidonske kiseline $(1 \mathrm{mmol} / \mathrm{L})$, epinefrina $(5,5$ $\mu \mathrm{mol} / \mathrm{L})$, ristocetina $(1,25 \mathrm{mg} / \mathrm{mL})$ i trombina $(1 \mathrm{U} / \mathrm{mL})$. Ispitan je uticaj aspirina na agregaciju trombocita i oslobađanje granula.

Rezultati: Neparametarskim pristupom je izračunat RI dobijen od 40 zdravih odraslih osoba. Za slabe agoniste su određeni širi intervali sa nižim donjim granicama. Oslabljena agregacija ili njeno odsustvo je pronađeno kod najvišše jedne od sedam zdravih osoba iz kontrolne grupe. Reakcija trombocita na aspirin je uporediva sa ranije objavljenim ispitivanjima.

Address for correspondence:

Alenka Trampuš Bakija

Institute of Special Laboratory Diagnostic

University Children's Hospital, UMC

20 Bohori eva Street, 1000 Ljubljana, Slovenia

fax: +38615229357

e-mail: alenka.trampus@kclj.si

List of abbreviations: ADP, adenosine diphosphate; ATP, adenosine triphosphate; $\mathrm{CV}$, coefficient of variation; LTA, light transmission aggregation; NA, not assayed; PPP, platelet- poor plasma; PRP, platelet-rich plasma; RI, reference interval; $S D$, standard deviation 
Conclusions: Locally established RI in our study enable us to investigate platelet function in patients with a high probability of bleeding disorders. Values are agonist and equipment specific. The variability of the method can be reduced by considering standardized preanalytical and analytical variables. Pathological results must be interpreted in the context of other hemostasis test results and clinical findings.

Keywords: blood platelets, platelet aggregation, platelet function test, reference values

\section{Introduction}

The evaluation of platelet function by light transmission aggregation (LTA) or lumiaggregation is a gold standard for patients with platelet function defects. Both assays are time-consuming and technically challenging. In spite of that, the method is recommended as a first-line test in platelet dysfunction diagnostic workup (1). Abnormal bleeding, as a consequence of altered platelet generation or activation, may lead to a severe clinical condition. The discrimination between inherited and acquired conditions is a difficult task for clinicians but crucial for adequate management of patients. Acquired conditions are more frequent, while the incidence of inherited platelet dysfunction is ranging from 1/1.000.000 to $1 / 100$ for some mild defects (2). In both types, the examination of clinical history is followed by preliminary laboratory tests: peripheral blood platelet count with smear examination, activated thromboplastin time, prothrombin time, thrombin time, fibrinogen concentration, and von Willebrand disease screening. Those methods are well standardized and worldwide accessible. Most second and third step tests (i.e. LTA, granule release, flow cytometry, electron microscopy) are much less standardized, and usually they are performed in specialized laboratories. Among them, LTA is the most commonly performed method, followed by platelet dense granule release test in smaller proportions $(3,4)$. Guideline documents for LTA are not uniform about the very best practice in performing and interpreting test results (5-8). For proper interpretation, each laboratory should establish its own approach to the diagnosis and cut-off values for distinguishing abnormal findings from a normal aggregation pattern. Rare genetic defects in platelet membrane proteins (i.e. Glanzmann thrombasthenia) have reproducible and characteristic profiles and are easily recognized. In addition to standard LTA method, simultaneous measurement of platelet secretion could be of greater value with inherited defect of platelet function as it shows greater sensitivity to much common mild disorders of platelet secretion (9-11). The aggregation response to antiplatelet agents (e. g. aspirin, clopidogrel) is well described but the monitoring with classical LTA is discouraged in clinical practice $(8,9)$. Several points of care tests (VerifyNow, Multiplate Electrode Aggregometry,
Zaključak: Lokalno utvrđeni RI u našem istraživanju omogućavaju nam da istražimo funkciju trombocita kod pacijenata sa velikom verovatnoćom poremećaja krvarenja. Vrednosti su specifične za agoniste i opremu. Varijabilnost metode se može smanjiti uzimajući u obzir standardizovane preanalitičke i analitičke promenljive. Patološki rezultati moraju da budu interpretirani u kontekstu drugih rezultata ispitivanja hemostaze i kliničkih nalaza.

Ključne reči: trombociti, agregacija trombocita, test funkcije trombocita, referentne vrednosti

Platelet function analyzer) have become available to monitor antiplatelet therapy. In spite of much evidence on diagnostic usefulness of (lumi)aggregometry, recent studies questioned the practical utility of dense granule release as the assay variability (especially for ATP release) is relatively high (CV>20\%) (12).

There are only four specialized laboratories in Slovenia where LTA can be performed and the laboratory at Children's hospital Ljubljana is the only one where lumiaggregometry for platelet function diagnostic workup is routinely done. The aim of the study was to measure plasma LTA and ATP secretion with several agonists to establish the analyzer-reagent reference intervals for adults. In addition, the utility of the test was validated in subjects receiving aspirin.

\section{Materials and Methods}

\section{Subjects}

Blood was collected from 45 healthy subjects, 26 females and 19 men, aged from 24 to 63. Exclusion criteria for volunteers were the absence of acute disease, absence of any medical therapy for 14 days, pregnancy and known coagulation disorder. Samples were collected from 8.00 to 10.00 am during two months period.

For acetylsalicylic acid effect monitoring, 11 volunteers from the above described same group of healthy subjects received aspirin in a single dose of $500 \mathrm{mg}$ (if body weight was up to $70 \mathrm{~kg}$ ) or $1000 \mathrm{mg}$ (if body weight was above $70 \mathrm{~kg}$ ) 24 hours prior to venepuncture.

Written study instructions were given, and informed consent was obtained from all participants. The study was approved by the National Medical Ethics Committee of the Republic of Slovenia (approval No 53/08/11) in accordance with the Helsinki Declaration.

\section{Methods}

Blood samples were collected into $0.109 \mathrm{~mol} / \mathrm{L}$ buffered sodium citrate tubes $(2 \times 4.5 \mathrm{~mL}$ Becton Dickinson, Franklin Lakes, NJ, USA). The samples 
were processed within a one-hour interval, and analysis was completed within four hours after blood collection.

Platelet-rich plasma (PRP) was prepared by centrifugation at $200 \times \mathrm{g}$ for 10 minutes at room temperature. Plasma from both collection tubes was transferred into a polypropylene tube and gently mixed. PRP was then adjusted to a count from 200 to $300 \times 10^{9}$ platelets/L, using autologous platelet-poor plasma (PPP) $(2500 \times \mathrm{g}, 15 \mathrm{~min})$. PRP was capped and kept at room temperature until further analyses. PRP with platelet count lower than $200 \times 10^{9} / \mathrm{L}$ was excluded from experiments. Platelet count in plasma was determined by AcT 8 hematology analyzer (Beckman Coulter, Fullerton, CA, USA).

Analyses were performed on lumiaggregometer Chrono-Log Model 700 (Chrono-Log Corp., Havertown, PA, USA) and data processed with software program Aggro/link 8 (Chrono-Log, Havertown, PA, USA).

The following Chrono-par ${ }^{\circledR}$ and Chronolume ${ }^{\circledR}$ reagents (all Chrono-Log, Havertown, PA, USA) in final concentrations in PRP were used in LTA and lumiaggregometry experiments: $\operatorname{ADP}(2 \mu \mathrm{mol} / \mathrm{L})$, collagen $(2 \mu \mathrm{g} / \mathrm{mL})$, arachidonic acid $(1 \mu \mathrm{mmol} / \mathrm{L})$, epinephrine $(5.5 \mu \mathrm{mol} / \mathrm{L})$, ristocetin $(1.25 \mathrm{mg} / \mathrm{mL})$, thrombin $(1 \mathrm{U} / \mathrm{mL})$ and ATP standard $(2 \mathrm{nmol})$. For lumiaggregometry we used luciferin-luciferase reagent $(0.2 \mu \mathrm{mol} / \mathrm{L})$.

ATP release was tested according to manufacturer instrument instructions using: $450 \mu \mathrm{L}$ of preincubated $\left(37^{\circ} \mathrm{C}, 3 \mathrm{~min}\right.$ ) PRP, $50 \mu \mathrm{L}$ of luciferase reagent, and $10-50 \mu \mathrm{L}$ of agonist. The aggregation and ATP release were monitored simultaneously at least 5 minutes after adding an agonist or 10 minutes if maximal aggregation was not achieved within 5 minutes (8). Results were reported as maximum aggregation (\%) and concentration of released ATP $(\mathrm{nmol} / \mathrm{L})$.

If the limited amount of sample was available, the reaction was performed with $225 \mu \mathrm{L}$ of plasma and adjusted volumes of all reagents.

\section{Statistical analysis}

Reference intervals (95\%, double-sided), ranging from 2.5 to 97.5 percentiles, were calculated using the non-parametric percentile method (CLSI C28-A3 guidelines) (13) since the distributions were normal after one elimination of suspected outliers (Turkey calculation). The statistical software Med$\mathrm{Calc}^{\circledR}$ (version 11.3.0.0., Frank Schoonjans, Mariakerke, Belgium) was used for analysis.

\section{Results}

Reference intervals for percentage of maximal aggregation for selected agonists are summarized in Table I. The number of control subjects for each agonist ranged from 38 to 44 . One set of values was used for each collected sample; some data have been excluded either due to low platelet count or as outliers. D'Agostino Pearson test indicates normal distribution for all agonists after the removal of outliers. Few results with no response (zero \% of aggregation) were observed for week agonist stimulation, and those were also excluded from calculation. The lowest lower reference limit was observed with ADP, while for other agonists values above $60 \%$ of maximal aggregation were observed. Thrombin, arachidonic acid, and collagen had highest lower RI limit for ATP release. In the sense of statistics, $0-4.7 \%$ of values of healthy control subjects $\left(0_{-} 2\right.$ results in the control population) exceeded the reference interval. The median platelet count in PRP was $274 \times 10^{9} / \mathrm{L}$ (range: $163-302 \times 10^{9} / \mathrm{L}$ ).

The effect of aspirin therapy on maximal aggregation and ATP release was tested on 11 healthy volunteers receiving acetylsalicylic acid before venipuncture. The response to selected agonists is described in Table II. In majority of samples, impaired aggregation to all agonists except for ristocetin and low ATP release with the exception of thrombin and collagen were determined. The assay showed $100 \%$ sensitivity

Table I Light transmission aggregation and ATP release reference intervals for adults. Statistical methods included nonparametric analyses.

\begin{tabular}{|c|c|c|c|}
\hline \multirow[t]{2}{*}{ Agonist } & \multirow[t]{2}{*}{$\begin{array}{c}\text { Final } \\
\text { concentration }\end{array}$} & \multicolumn{2}{|c|}{$\begin{array}{c}\text { Reference intervals } \\
\text { ( } n=\text { number of sample) }\end{array}$} \\
\hline & & $\begin{array}{l}\% \text { maximal } \\
\text { aggregation }\end{array}$ & $\begin{array}{c}\text { ATP } \\
\text { concentration } \\
(\mathrm{nmol})\end{array}$ \\
\hline ADP & $2 \mu \mathrm{mol} / \mathrm{L}$ & $\begin{array}{l}55-87 \\
(n=44)\end{array}$ & $\begin{array}{c}0.29-2.11 \\
(n=42)\end{array}$ \\
\hline Epinephrine & $5.5 \mu \mathrm{mol} / \mathrm{L}$ & $\begin{array}{l}63-92 \\
(n=38)\end{array}$ & $\begin{array}{c}0.22-2.60 \\
(n=38)\end{array}$ \\
\hline Collagen & $2 \mu \mathrm{g} / \mathrm{mL}$ & $\begin{array}{l}65-92 \\
(n=40)\end{array}$ & $\begin{array}{c}0.41-2.33 \\
(n=39)\end{array}$ \\
\hline $\begin{array}{l}\text { Arachidonic } \\
\text { acid }\end{array}$ & $1 \mathrm{mmol} / \mathrm{L}$ & $\begin{array}{l}62-85 \\
(n=41)\end{array}$ & $\begin{array}{c}0.49-2.46 \\
(n=38)\end{array}$ \\
\hline Ristocetin & $1.25 \mathrm{mg} / \mathrm{mL}$ & $\begin{array}{l}62-91 \\
(n=43)\end{array}$ & NA \\
\hline Thrombin & $1 \mathrm{U} / \mathrm{mL}$ & NA & $\begin{array}{c}0.50-2.85 \\
(n=42)\end{array}$ \\
\hline
\end{tabular}

ADP - adenosine diphosphate; ATP - adenosine triphosphate; NA - not assayed 
Table II Light transmission aggregation and ATP release level in subjects receiving acetylsalicylic acid.

\begin{tabular}{|l|c|c|c|c|}
\hline $\begin{array}{l}\text { Agonist (final } \\
\text { concentration) }\end{array}$ & $\begin{array}{c}\text { Lower RI limit \% } \\
\text { maximal } \\
\text { aggregation }\end{array}$ & $\begin{array}{c}\text { Average \% maximal } \\
\text { aggregation } \\
\text { (No. of reduced } \\
\text { responses/total) }\end{array}$ & $\begin{array}{c}\text { Lower RI } \\
\text { limit ATP } \\
\text { concentration } \\
\text { (nmol) }\end{array}$ & $\begin{array}{c}\text { Average ATP } \\
\text { concentration } \\
\text { (No. of reduced } \\
\text { responses/total) }\end{array}$ \\
\hline ADP $(2 \mu \mathrm{mol} / \mathrm{L})$ & 55 & $51(6 / 11)$ & 0.29 & $0.0(11 / 11)$ \\
\hline Epinephrine $(5.5 \mu \mathrm{mol} / \mathrm{L})$ & 63 & $19(11 / 11)$ & 0.22 & $0.0(11 / 11)$ \\
\hline Collagen $(2 \mu \mathrm{g} / \mathrm{mL})$ & 65 & $36(11 / 11)$ & 0.41 & $0.50(6 / 11)$ \\
\hline Arachidonic $\mathrm{acid}(1 \mathrm{mmol} / \mathrm{L})$ & 62 & $5(11 / 11)$ & 0.49 & $0.0(11 / 11)$ \\
\hline Ristocetin $(1.25 \mathrm{mg} / \mathrm{mL})$ & 62 & $70(2 / 11)$ & $\mathrm{NA}$ & $\mathrm{NA}$ \\
\hline Thrombin $(1 \mathrm{U} / \mathrm{mL})$ & $\mathrm{NA}$ & $\mathrm{NA}$ & 0.50 & $1.04(2 / 11)$ \\
\hline
\end{tabular}

The table presents average responses to agonists in comparison to the lower reference interval limit. Arachidonic acid and epinephrine show maximum sensitivity to acetylsalicylic acid.

RI - reference interval; NA - not assayed; ADP - adenosine diphosphate; ATP - adenosine triphosphate

for aggregation response to epinephrine $5.5 \mu \mathrm{mol} / \mathrm{L}$, collagen $2 \mu \mathrm{mol} / \mathrm{mL}$ and arachidonic acid $1 \mathrm{mmol} / \mathrm{L}$ as well as for ATP release level induced with ADP 2 $\mu \mathrm{mol} / \mathrm{L}$, epinephrine $5.5 \mu \mathrm{mol} / \mathrm{L}$ and arachidonic acid $1 \mathrm{mmol} / \mathrm{L}$.

\section{Discussion}

The primary goal of our study was to establish a reference interval for maximal aggregation and ATP release in adults, measured by the lumiaggregometric method. Published Rls are usually not transferable and should be established in the local laboratory (13). The standardization of the aggregometry methods is still lacking and is under investigation. As many as possible preanalytical and analytical variables need to be standardized to assure low variability of the results. In our study, we considered recommendation from different guidelines and evidence-based practices. Variability was reduced by taking fasting sample, venipuncture by the same experienced phlebotomist, time of sampling (before $10 \mathrm{am}$ ), time to process the sample (within one hour), time to analyze the sample (within four hours), usage of the same trademark of blood collection material, adjusting PRP count to $200-300 \times 10^{9}$ platelets/L, capping tubes before analysis, resting platelets after centrifugation (at least 30 minutes), performing test at constant room temperature $\left(21-25^{\circ} \mathrm{C}\right)$, using same laboratory equipment and assaying the tests by the same technician. Hemolyzed, lipemic, coagulated, thrombocytopenic samples or underfilled tubes were not analyzed. We used the basic agonist panel and concentrations as it is recommended by international, European and North American guidelines (6-8). Low to moderate concentrations of ADP, epinephrine and collagen were chosen to detect the $\delta$-storage pool deficiency.
When method verification is performed, standard reference material could be of great importance. Unfortunately, in the case of platelet function tests, there is no such material available, so the traceability of analytical system is not possible. Therefore, the procedure cannot be performed to the same extent as with more standardized tests for hemostasis. The challenge to establish reference interval is even higher when the analysis must be performed on fresh blood samples when several preanalytical influences could be present. Moreover, last but not least is the cost of the analysis which is considerable. Practices from external quality control schemes show that less than half of participants validate $\mathrm{Rl}$, including a low number of healthy volunteers (reported by Hayward on ISLH meeting; Vancouver 2019).

In our study, approximately 40 subjects were included in each agonist group. The group is too small for using the parametric statistical approach; therefore, we used a non-parametrical method to establish intervals as recommended by guidelines of British Society for Hematology (7). This approach is also suitable for the analysis of not normally distributed data. The sample size below 120 cannot provide coverage probabilities so the confidence intervals for low in high limits could not be calculated. We reported the intervals with lower and upper limits, though values below lower limits are clinically relevant for diagnosis of platelet function disorder. The shape of the curve is subjectively evaluated concomitantly.

The comparison of our findings with the existing publications is difficult due to usage of different equipment, reagents, concentrations of agonists and statistical approach. The manufacturer (Chrono-Log) normal ranges were obtained from various publications and serve as a guideline only. Similar to our findings, the lowest minimum aggregation response with 
ADP and minimum ATP release with epinephrine (mean \pm 1 SD) was stated. In general, majority of researchers reported broad reference intervals for week agonists (ADP, epinephrine) and narrow ones for strong agonists (arachidonic acid, ristocetin) induced aggregation/agglutination (11, 14-16). Some studies reported very low values for lower RI limit when using week agonists. Absence or impaired aggregation is found in up to one of seven healthy controls $(11,14,16,17)$. In our study, we found absent or reduced response for epinephrine and ADP after 10 minutes of recording in five and two healthy subjects, respectively. These results were excluded from the statistical calculation. The interpretation of per se pathological results when subject's bleeding history is negative is not considered abnormal (18). The heterogeneity of published RI for ATP release is even broader. It is well known that the variability for ATP release assay is up to $30 \%$ and that the test has high specificity and moderate sensitivity (19-21). This fact is recently raising question about the usefulness of the assay (4).

Further, examination of primary hemostasis and platelet function in children is challenging and poorly investigated. Pediatric RI is hard to establish due to ethical issues. According to published data (15, 2224), RI for adults can be used for the interpretation of results in children older than one year, and this practice was accepted in our laboratory as well. North American Specialized Coagulation Laboratory Association - NASCOLA consensus agreement is even less strict and the usage of LTA RI for adults and children beyond neonatal period is recommended (6).

The limitation of the present study is the number of healthy volunteers to assure the sufficient statistical power of the RI calculation (less than 120). Also, verification of the test's precision was not possible. Multiple sampling of the same patients is difficult to

\section{References}

1. Gresele P, for Subcommittee on Platelet Physiology of the International Society on Thrombosis and Hemostasis. Diagnosis of inherited platelet function disorders: guidance from the SSC of the ISTH. J Thromb Haemost 2015; 13: 314-22.

2. Gresele P, Falcinelli E, Bury L. Laboratory diagnosis of clinically relevant platelet function disorders. Int J Lab Hematol 2018; 40: Suppl 1: 34-45.

3. Hayward CPM, Moffat KA, Plumhoff E, Timleck M, Hoffman S, Spitzer E, et al. External quality assessment of platelet disorder investigations: results of international surveys on diagnostic tests for dense granule deficiency and platelet aggregometry interpretation. Semin Thromb Hemost 2012; 38: 622-31.

4. Hayward CPM, Moffat KA, Brunet J, Carlino SA, Plumhoff E, Meijer P, et al. Update on diagnostic testing perform and no standardized material has been available so far. If possible, a healthy control subject's sample should be run in parallel with a patient's sample. The reported RI is not validated for PRP with low platelet count. Derived limits and agonist panel were recommended for thrombocytopenic patients $(8,14)$. In our study, the response of platelets to acetylsalicylic acid was monitored in order to verify the usefulness of the test and not for the clinical interpretation of antiplatelet therapy. The characteristic absent aggregation and ATP release due to absent cyclooxygenase activity were found in arachidonic acid and epinephrine induced activation. ADP and collagen lower sensitivity is in agreement with previously reported studies showing a very good overall sensitivity of a method to aspirin-like defects (25). In addition, to confirm an aspirin-like defect (drug-induced or inherited) it would be reasonable to include a thromboxane analogue in the agonist panel.

The above presented locally established RI enables us to investigate platelet function and granule release/storage abnormalities by measuring the LTA and ATP release in patients with high probability of platelet disorders. In case of possible false-positive results, the test should be repeated another day with higher agonist concentrations. Pathological results should always be interpreted in the context of clinical findings. Our results provide RI that could be used or validated by other laboratories using similar local technical conditions in order to interpret results accordingly.

Acknowledgments. The authors thank Mojca Juretič for technical support.

\section{Conflict of interest statement}

The authors state that they have no conflicts of interest regarding the publication of this article.

for platelet function disorders: What is practical and useful? Int J Lab Hematol 2019; 41: Suppl 1: 26-32.

5. CLSI. Platelet Function Testing by Aggregometry; approved guideline. CLSI document H58-A. Wayne, PA: Clinical and Laboratory Standard Institute, 2008.

6. Hayward CPM, Moffat KA, Raby A, Israels S, Plumhoff E, Flynn G, et al. Development of North American consensus guidelines for medical laboratories that perform and interpret platelet function testing using light transmission aggregometry. Am J Clin Pathol 2010; 134: 955-63.

7. Harrison P, Mackie I, Mumford A, Briggs C, Liesner R, Winter $M$, et al. Guidelines for the laboratory investigation of heritable disorders of platelet function. $\mathrm{Br} \mathrm{J}$ Haematol 2011; 155: 30-44.

8. Cattaneo M, Cerletti C, Harrison P, Hayward CPM, Kenny $D$, Nugent $D$, et al. Recommendations for the Stan- 
dardization of Light Transmission Aggregometry: A Consensus of the Working Party from the Platelet Physiology Subcommittee of SSC/ISTH. J Thromb Haemost 2013; 2013: 1183-9.

9. Cattaneo M. Light transmission aggregometry and ATP release for the diagnostic assessment of platelet function. Semin Thromb Hemost 2009; 35: 158-67.

10. Nieuwenhuis HK, Akkerman JW, Sixma JJ. Patients with a prolonged bleeding time and normal aggregation tests may have storage pool deficiency: studies on one hundred six patients. Blood 1987; 70: 620-3.

11. Quiroga T, Goycoolea M, Matus V, Zúñiga P, Martínez C, Garrido $M$, et al. Diagnosis of mild platelet function disorders. Reliability and usefulness of light transmission platelet aggregation and serotonin secretion assays. $\mathrm{Br} \mathrm{J}$ Haematol 2009; 147: 729-36.

12. Badin MS, Graf L, lyer JK, Moffat KA, Seecharan JL, Hayward CPM. Variability in platelet dense granule adenosine triphosphate release findings amongst patients tested multiple times as part of an assessment for a bleeding disorder. Int J Lab Hematol 2016; 38: 648-57.

13. CLSI. Define and Verify Reference Intervals in the Clinical Laboratory; approved guideline - third edition. CLSI document EP28A3c. Wayne, PA: Clinical and Laboratory Standard Institute; 2008.

14. Hayward CPM, Moffat KA, Pai M, Liu Y, Seecharan J, McKay $\mathrm{H}$, et al. An evaluation of methods for determining reference intervals for light transmission platelet aggregation tests on samples with normal or reduced platelet counts. Thromb Haemost 2008; 100: 134-45.

15. Knöfler R, Streif W. Strategies in Clinical and Laboratory Diagnosis of Inherited Platelet Function Disorders in Children. Transfus Med Hemother 2010; 37: 231-5.

16. Platton S, McCormick Á, Bukht M, Gurney D, Holding I, Moore GW. A multicenter study to evaluate automated platelet aggregometry on Sysmex CS-series coagulation analyzers-preliminary findings. Res Pract Thromb Haemost 2018; 2: 778-89.
17. Mezzano D, Quiroga T, Pereira J. The level of laboratory testing required for diagnosis or exclusion of a platelet function disorder using platelet aggregation and secretion assays. Semin Thromb Hemost 2009; 35: 242-54.

18. Zhou L, Schmaier AH. Platelet aggregation testing in platelet-rich plasma: description of procedures with the aim to develop standards in the field. Am J Clin Pathol 2005; 123: 172-83.

19. Pai M, Wang G, Moffat KA, Liu Y, Seecharan J, Webert $K$, et al. Diagnostic usefulness of a lumi-aggregometer adenosine triphosphate release assay for the assessment of platelet function disorders. Am J Clin Pathol 2011; 136: 350-8.

20. Brunet JG, lyer JK, Badin MS, Graf L, Moffat KA, Timleck $M$, et al. Electron microscopy examination of platelet whole mount preparations to quantitate platelet dense granule numbers: Implications for diagnosing suspected platelet function disorders due to dense granule deficiency. Int J Lab Hematol 2018; 40: 400-7.

21. Castilloux JF, Moffat KA, Liu Y, Seecharan J, Pai M, Hayward CPM. A prospective cohort study of light transmission platelet aggregometry for bleeding disorders: is testing native platelet-rich plasma non-inferior to testing platelet count adjusted samples? Thromb Haemost 2011; 106: 675-82.

22. Bonduel M, Frontroth JP, Hepner M, Sciuccati G, FeliúTorres A. Platelet aggregation and adenosine triphosphate release values in children and adults. J Thromb Haemost 2007; 5: 1782-3.

23. Hvas AM, Favaloro EJ. Platelet function testing in pediatric patients. Expert Rev Hematol 2017; 10: 281-8.

24. Ravn HB, Andreasen JB, Hvas AM. Does whole blood coagulation analysis reflect developmental haemostasis? Blood Coagul Fibrinolysis 2017; 28: 218-23.

25. Taylor MI, Misso NLA, Stewart GA, Thompson PJ. The effect of varying doses of aspirin on human platelet activation induced by PAF, Collagen and arachidonic acid. $\mathrm{Br}$ J Clin Pharmac 1992; 33: 25-31. 